\title{
Fire history and dendroecology of Catoctin Mountain, Maryland, USA, with newspaper corroboration
}

\author{
Lauren F. Howard ${ }^{1 *}$ (D), Gabriel D. Cahalan², Kristyn Ehleben ${ }^{1}$, Baaqeyah Amala Muhammad El ${ }^{1}$, Hope Halza ${ }^{1}$ and \\ Stephen DeLeon ${ }^{1}$
}

\begin{abstract}
Background: Our study was designed to reveal a detailed forest fire history at Catoctin Mountain Park, Maryland, USA. We compared the ages of living trees to known fire dates in the dendrochronological record. Seasonality and years of fires in the dendrochronological record were juxtaposed with specific dates of fires recorded in newspapers.

Results: Twenty-seven pines (Pinus L.) captured 122 fire scars representing 58 distinct fire years between 1702 and 1951. Climate was significantly hotter and drier in the years of burns that affected at least two trees and was wetter two years prior. Thirty-three fires described in local newspapers were reported largely in the spring and fall months (68\% between March and June, 32\% between September and December). Ninety-one percent of fire scars in our tree-ring chronology had dormant seasonality. The mean fire interval was $5.47 \pm 10.14$ (SD; standard deviation) yr, and the Weibull median fire interval was $3.22 \mathrm{yr}$ during the entire chronology. The longest fire-free interval was from 1952 to 2018.

The size structure of living trees was biased toward smaller black gums (Nyssa sylvatica Marshall) and oaks (Quercus L.) that recruited in the 1930s and 1940s. Most living pitch pines (Pinus rigida Mill) recruited between 1890 and 1910, but a few individuals recruited before the 1850s. Diversity of tree stems smaller than $10 \mathrm{~cm}$ diameter at breast height (DBH) was generally lacking; the youngest tree $>10 \mathrm{~cm}$ DBH in our study area had recruited by 1967 .

Conclusions: The Catoctin Mountains experienced frequent fire during the 1800s and early 1900s. The causes of fires were diverse, including accidental ignitions and purposeful cultural burning for berry (Vaccinium L.) production. The current forest developed during a period of low deer density and after the demise of the charcoal iron industry ended an era of logging. The lack of fire since the 1950s has encouraged the development of a black gum dominated midand understory. Management with frequent fire would facilitate pine and oak regeneration.
\end{abstract}

Keywords: Appalachian Mountains, charcoal-iron industry, dendrochronology, fire frequency, mesophication, newspapers, Nyssa sylvatica Marshall, Pinus rigida Mill., Quercus spp., Vaccinium spp.

\footnotetext{
* Correspondence: howardl@arcadia.edu

${ }^{1}$ Department of Biology, Arcadia University, 450 S. Easton Road, Glenside,

Pennsylvania 19038, USA

Full list of author information is available at the end of the article
}

\section{Springer Open}

๑) The Author(s). 2021 Open Access This article is licensed under a Creative Commons Attribution 4.0 International License, which permits use, sharing, adaptation, distribution and reproduction in any medium or format, as long as you give appropriate credit to the original author(s) and the source, provide a link to the Creative Commons licence, and indicate if changes were made. The images or other third party material in this article are included in the article's Creative Commons licence, unless indicated otherwise in a credit line to the material. If material is not included in the article's Creative Commons licence and your intended use is not permitted by statutory regulation or exceeds the permitted use, you will need to obtain permission directly from the copyright holder. To view a copy of this licence, visit http://creativecommons.org/licenses/by/4.0/. 


\section{Resumen}

Antecedentes: Nuestro trabajo fue diseñado para exponer una detallada historia del fuego en el Parque de las Montañas Catoctin, en Maryland, EEUU. Comparamos las edades de árboles vivos con fechas de fuegos conocidas a través del registro dendrocronológico. La estacionalidad y años de incendios tomados del registro dendrocronológico fueron yuxtapuestos con datos específicos de incendios registrados por los periódicos locales.

Resultados: Veintisiete pinos (Pinus L.) registraron 122 cicatrices de fuegos, representado 58 años diferentes de ocurrencia de incendios desde 1702 hasta 1951. El clima fue significativamente más cálido y seco en los años de fuego en que fueron afectados al menos dos árboles, y que su vez los dos años previos al incendio fueron más húmedos. Treinta y tres incendios descriptos en diarios locales fueron reportados mayoritariamente durante los meses de primavera y otoño (68\% entre marzo y junio, 32\% entre septiembre y diciembre). Noventa y uno por ciento de las cicatrices de fuego en nuestra cronología de recuento de anillos tuvieron dormancia estacional. El intervalo medio entre fuegos fue de 5,47 \pm 10,14 años, (SD; desviación estándar) y la mediana de Weibull de intervalo entre fuegos fue de 3,22 años durante toda la cronología. El intervalo más alto de períodos sin fuegos fue de 1952 a 2018.

El tamaño de la estructura de los árboles vivos estuvo sesgado hacia pequeños tupelos (Nyssa sylvatica Marshall) y robles (Quercus L.) reclutados entre los años 1930 y 1940s. La mayoría de los árboles vivos del pino bronco (Pinus rigida Mill) se reclutaron entre 1890 y 1910, y muy pocos individuos fueron reclutados antes de 1850s. La diversidad de tallos de árboles menores a $10 \mathrm{~cm}$ de diámetro a la altura del pecho (DAP) estuvo generalmente ausente; el árbol más joven con DAP >10 cm en nuestra área de estudio fue reclutado en 1967.

Conclusiones: Las Montañas Catoctin experimentaron fuegos frecuentes durante los años 1800 y principios de 1900s. Las causas de los incendios fueron diversas, incluyendo igniciones accidentales e intencionales con el propósito cultural de promover la producción de arándanos (Vaccinium L.). El bosque actual se desarrolló durante el período de baja densidad de ciervos y después de que la industria del hierro cesara el uso carbón de leña, lo que finalizó con una era de tala de esos bosques. La falta de fuegos desde los años 1950s ha promovido el desarrollo del tupelo en el dosel medio y bajo. El manejo con fuegos más frecuentes podría facilitar la regeneración de pinos y robles.

\author{
Abbreviations \\ CCC: Civilian Conservation Corps \\ DBH: Diameter at Breast Height \\ GIS: Global Information Systems \\ GPS: Global Positioning System \\ MFI: Mean Fire Interval \\ NPS: National Park Service \\ PDSI: Palmer Drought Severity Index \\ SEA: Superposed Epoch Analysis \\ WMI: Weibull Median Interval
}

\section{Background}

Fire-adapted ecosystems in the eastern US, such as oakpine (Pinus L.-Quercus L.) woodlands and forests, were much more prevalent in the past when fire was common across the landscape. The composition of pre-colonial forests has been reconstructed from witness trees (Abrams 2003; Thomas-VanGundy and Nowacki 2013; Thomas-VanGundy et al. 2015; Briand and Folkoff 2019), palynological evidence (Brush 2001; Willard et al. 2003; Ballard et al. 2017; Horn et al. 2019), and archaeological dendrochronology (Grissino-Mayer et al. 2013; de Graauw and Hessl 2020), and pyrophilic species (e.g., oaks and pines) were common. Direct evidence of fire is present in sediment cores (Brush 2001; Mitra et al. 2009; Horn et al. 2019), in soils as charcoal (Kirwan and Shugart 2000; Hart et al. 2008; Howard 2015), and in fire-scarred trees (Brose et al. 2014; Lafon et al. 2017; Stambaugh et al. 2018). Microscopic charcoal in sediment cores collected from the Chesapeake Bay aligns with climatically dry periods in the wider watershed and airshed (Mitra et al. 2009). Although fires have been uncommon in the Central Appalachian region since the mid twentieth century because of active fire suppression, models of climate, fuels, and vegetation show that the eastern US has been predisposed toward flammability for thousands of years (Guyette et al. 2012).

Tree-ring research from the Appalachian Mountains in the eastern US has consistently shown mean fire intervals less than ten years prior to the 1930s (the beginning of the fire suppression era), dormant seasonality, and reduction or lack of fires by the 1930s to 1950s (Hessl et al. 2011; Brose et al. 2013; Flatley et al. 2013; Silver et al. 2013; Aldrich et al. 2014; Marschall et al. 2016; Saladyga 2017 and Stambaugh et al. 2018). All but the most recent studies were included in regional reviews by Brose et al. (2014) and Lafon et al. (2017). 
Understanding the historical range of variation in these factors and processes is an important component of designing fire management plans for ecological restoration that conserve fire-dependent flora and fauna (Frost 1998; Keane et al. 2009; Beller et al. 2020). Thus, fire history studies fill a critical need in the management of Central Appalachian ecosystems.

Although patterns of historical fire are becoming better known across the eastern US, few studies have been conducted in the state of Maryland. Dendrochronological work on fire history in Maryland so far includes Shumway et al. (2001) and Dobey et al. (1987). Shumway et al. (2001) focused on 20 stumps of an old-growth oak stand in Garrett County that had been logged in 1986. They found evidence of 42 historical fires ranging from 1616 to 1959, with a Weibull modal fire interval of 7.6 yr. Dobey et al. (1987) dated eight white and pitch pines (Pinus strobus L. and Pinus rigida Mill, respectively) cut from the same area as our current study on Catoctin Mountain in Frederick County. In their study, the fire intervals recorded by the trees ranged from 5 to $49 \mathrm{yr}($ mean $=21.5 \mathrm{yr})$, and fires occurred between 1876 and 1936. This study quoted a local resident as saying that income from berry (Vaccinium L.) picking necessitated customary burning in the area between 1901 and 1935 (Dobey et al. 1987). While the authors referenced the charcoaling that occurred on the mountain prior to the twentieth century, a prolonged absence of fire scars between 1813 and 1876 seemed to indicate that this practice was not a major driver of fires. We suspected that a larger sample size would show that the fire interval was actually shorter than the Dobey et al. (1987) resultant mean fire interval (MFI) of $21.5 \mathrm{yr}$ at Catoctin Mountain and closer to what has been documented in the Appalachian Mountains.

We focused our study on Catoctin Mountain because it presented a unique opportunity to study fire history alongside its cultural context, which Harley et al. (2018) and Roos et al. (2019) identified as a gap in knowledge for fire history research. Unlike the remote locations of many other fire history studies in the Appalachian Mountains (e.g., study area of Shumway et al. 2001), Catoctin Mountain is located close to major population centers, allowing for a detailed newspaper record of fires. Newspaper articles from Frederick, Hagerstown, Baltimore, and Thurmont revealed the anthropogenic and landscape contexts of these historic fires, and allowed us to pinpoint exact ignition dates to compare to dendrochronological seasonality and historical weather data. We sought to juxtapose historical descriptions and current forest composition data to link Catoctin Mountain's ecology to its past land use and extrapolate possible futures under different management regimes.

\section{Methods}

\section{Study area}

Our study was conducted at Catoctin Mountain Park, a national park located west of the town of Thurmont in Frederick County, Maryland, USA (longitude: $-77.450255^{\circ}$, latitude: $\left.39.634109^{\circ}\right)$. The study area was located north of route MD-77, Rocky Ridge Road, between the visitor's center to the west and the park office to the east (Fig. 1). The site was in the Blue Ridge Province of the Appalachian Mountains. The stratigraphy was mapped as the Chilhowee Group-Weverton and Loudoun Formations, which are primarily light gray to gray quartzite, metaconglomerate, phyllite, and metagraywacke (Whitaker 1955; Brezinski 1992; National Park Service 2020a). The soils were mapped as Stumptown-Bagtown-Rock outcrop complex and Bagtown cobbly loam (USDA 2020). The mean maximum annual temperature was $15.9{ }^{\circ} \mathrm{C}$ while the minimum was $6.1{ }^{\circ} \mathrm{C}$. The mean annual precipitation was $124 \mathrm{~cm}$ per year and evenly distributed throughout the year, ranging from $8.1 \mathrm{~cm}$ (February) to $12.9 \mathrm{~cm}$ (September) (Western Regional Climate Center 2020). Typical vegetation was characterized as Central Appalachian Pine-Oak/Heath Woodland (NatureServe 2021). We consulted primary and secondary sources to construct a cultural history timeline for the study site (Additional file 1).

\section{Fire history}

We applied a Geographic Information Systems (GIS) aspect-slope filter to search the most likely locations for fire-scarred trees, based on a slope of at least $20^{\circ}$ and a southern or western aspect (170 to $300^{\circ}$ azimuth). These criteria highlighted the driest environmental conditions and often corresponded with locations of pines. Fire scars were most likely to be found on the uphill sides of trees or on the underside of fallen logs, where standing dead trees later fell in the direction of the "catface" (Yocom Kent and Fulé 2015; Additional file 2).

Once a fire-scarred tree was found, its position was recorded using Geographic Positioning System (GPS), then photographed, identified to species (or genus for longdead trees), and measured for diameter at breast height (DBH). We collected sections approximately 5 to $7 \mathrm{~cm}$ thick or, for living pines, we collected partial pie-sliceshaped sections of a similar thickness from one side of the catface (Arno and Sneck 1977). Following Speer (2012), wood samples were progressively sanded from P80 to P1200 grit sandpaper so that a clear view of xylem tracheids and annual ring boundaries could be examined. We developed a chronology by cross-dating tree cores collected from 23 live pitch pine trees, which was then used to fit the deadwood pine samples into the chronology and determine years and seasons of fire scars. Cross-dating was accomplished using visual and 


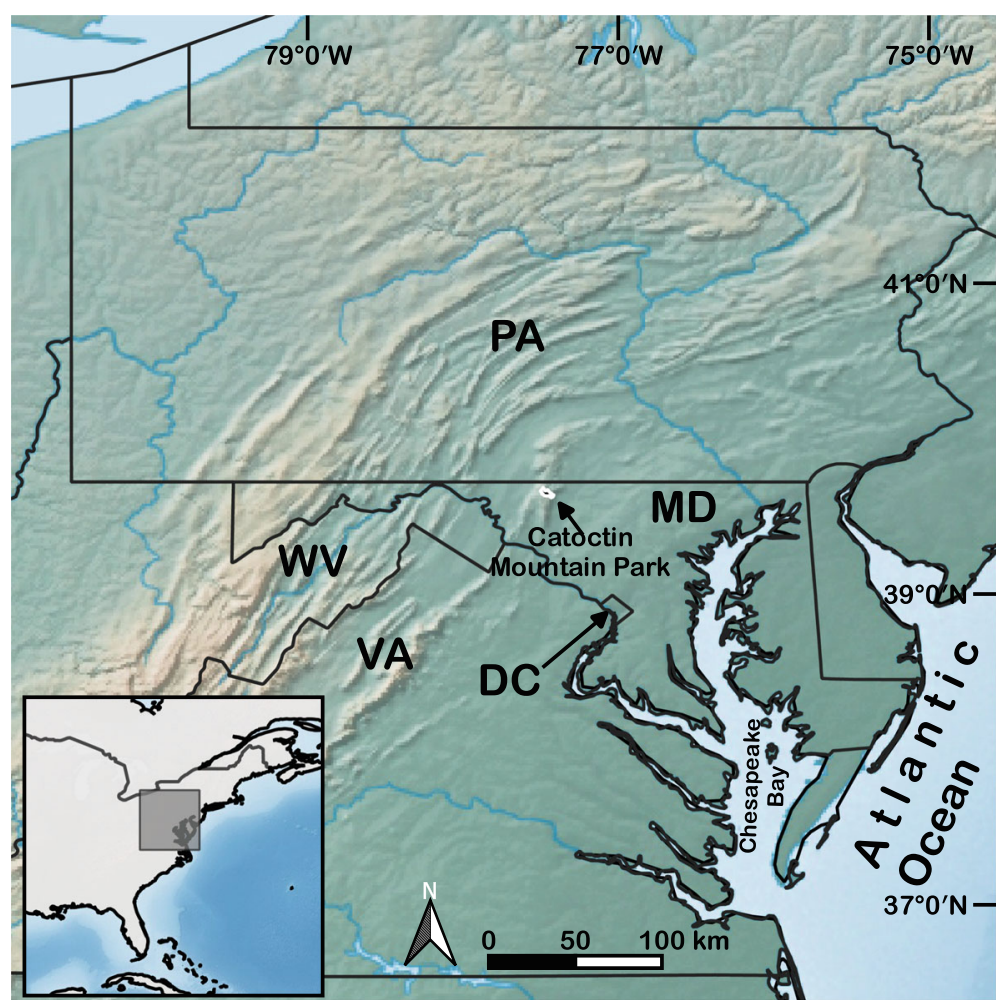

Fig. 1 Location of our fire history study conducted in 2018 at Catoctin Mountain Park in Frederick County, Maryland, USA. Location abbreviations: $D C=$ Washington, District of Columbia.; $M D=$ Maryland; $P A=$ Pennsylvania; $V A=$ Virginia; $W=$ West Virginia

statistical methods to ensure accuracy (Bunn 2008, 2010; Speer 2012; Brewer 2014; R core team 2019).

We calculated mean fire interval (MFI) and Weibull median interval (WMI) of the study area using all fires, and again for fires that scarred at least two trees in the same year using Fire History Analysis and Exploration System (FHAES; Sutherland et al. 2016). The fire-free period after the last fire was included as an interval. We calculated the percentage of fires occurring in each seasonality category over the entire period of record.

We compared dates of fires in the dendrochronological record with those in the following periodicals: Washington Post, Baltimore Sun, Catoctin Whig, Catoctin Clarion, Frederick News-Post, and Hagerstown Herald. The online search terms we used were: fire, wildfire, and forest fire. Microfiche archives at local libraries were also searched using dates from the tree-ring record to guide the search. Fire events that had a referenced location that referred to "Catoctin" or the surrounding area in Frederick and Washington counties in Maryland were used for our analysis. We also consulted maps from the Library of Congress to narrow down the time period in which railroads were built in the Catoctin Mountain area. We analyzed MFI and WMI of newspaper fire dates in FHAES, using a dormant season cutoff date of 1 November. If the event occurred on or after 1 November, it was entered for the following year.
We used a two-tailed Welch two sample $t$-test (Welch 1938) and a Superposed Epoch Analysis (SEA) using the sea function in the burnr package in $\mathrm{R}$ (Malevich et al. 2018) to compare the occurrence of historical fire scars with the mean Palmer Drought Severity Index (PDSI; Wells et al. 2004). PDSI data for June through August of each year was compiled from 1600 to 2005 for the specific region of Maryland surrounding the study site (North American Drought Atlas 2019 and Cook et al. 2010 for the polygon $39.34^{\circ} \mathrm{N}$ to $39.93^{\circ} \mathrm{N}, 78.93^{\circ} \mathrm{W}$ to $\left.77.21^{\circ} \mathrm{W}\right)$. We divided PDSI values into two groups: PDSI values in years in which we found only one tree scarred, and compared it to PDSI values in the group of years in which we found more than one scarred tree in our sample. We confirmed that PDSI data were normally distributed using Shapiro-Wilks' test (Razali and Wah 2011) prior to performing the $\mathrm{T}$ test, because normally distributed datasets are an underlying assumption (Shapiro-Wilks $P=0.67$ for single-tree fire years and $P=0.74$ for fire years that scarred two or more trees).

\section{Current forest composition}

Current vegetation at the study area was sampled inside two sets of nested plots that were positioned using a restricted random technique to be at least $100 \mathrm{~m}$ from a 
vegetation boundary. For each plot center, we noted slope, aspect, and deer impact (scale of 1 to 5 , with 5 being the highest). Trees greater than $10 \mathrm{~cm}$ DBH were sampled within a $500 \mathrm{~m}^{2}$ circular plot. The species, $\mathrm{DBH}$, canopy class (suppressed, intermediate, codominant, dominant), and status (living, standing dead, down dead) were noted. If the tree was not hollow, it was cored twice from just above the root collar (approximately $30 \mathrm{~cm}$ above the ground surface). Saplings (smaller than $10 \mathrm{~cm}$ DBH but greater than breast height) were tallied inside of $50 \mathrm{~m}^{2}$ circular plots and were not cored. Ground flora was quantified inside four $1 \mathrm{~m}^{2}$ plots using percent cover classes $(<1 \%, 1$ to $5 \%, 5$ to $25 \%, 25$ to $50 \%, 50$ to $75 \%, 75$ to $100 \%$ ). Tree seedlings were tallied if they were at least $5 \mathrm{~cm}$ tall with at least two normal-sized leaves, and their regeneration source (stump sprout, seedling, competitive seedling [root collar diameter $=1.9$ to $2.54 \mathrm{~cm}]$ ) was recorded (Brose et al. 2008). We recorded leaf-litter depth and duff depth at 12 points across the study area using traditional planar intercept sampling (Brown 1974).

We characterized the composition and structure of the present-day tree community using the following: absolute density (individuals per hectare), relative density (percentage of all individuals), absolute basal area (square meters per hectare), and relative basal area (percentage of basal area). Abundance of shrubs, herbs, and seedlings was the mean percent cover of each species. Seedlings per hectare of each tree species were also calculated. To facilitate interpretation of forest dynamics, we examined size structure using $\mathrm{DBH}$ data and determined age structure from cores. Age was estimated within decadal categories using ring counts.

\section{Results}

\section{Fire history}

Twenty-seven pine trees with fire scars were sampled with date coverage from 1652 to 2018. The interseries correlation of our chronology including both pine cores and fire-scarred sections was 0.51 , and 0.42 when only fire-scarred samples were used. We identified 122 fire scars and 13 injuries representing 58 distinct fire years between 1702 and 1951 (Fig. 2). The mean fire interval (MFI) was $5.47 \pm 10.14$ (SD) yr, and the Weibull median fire interval (WMI) was $3.22 \mathrm{yr}$. The longest fire-free interval was from 1952 to 2018. One hundred five

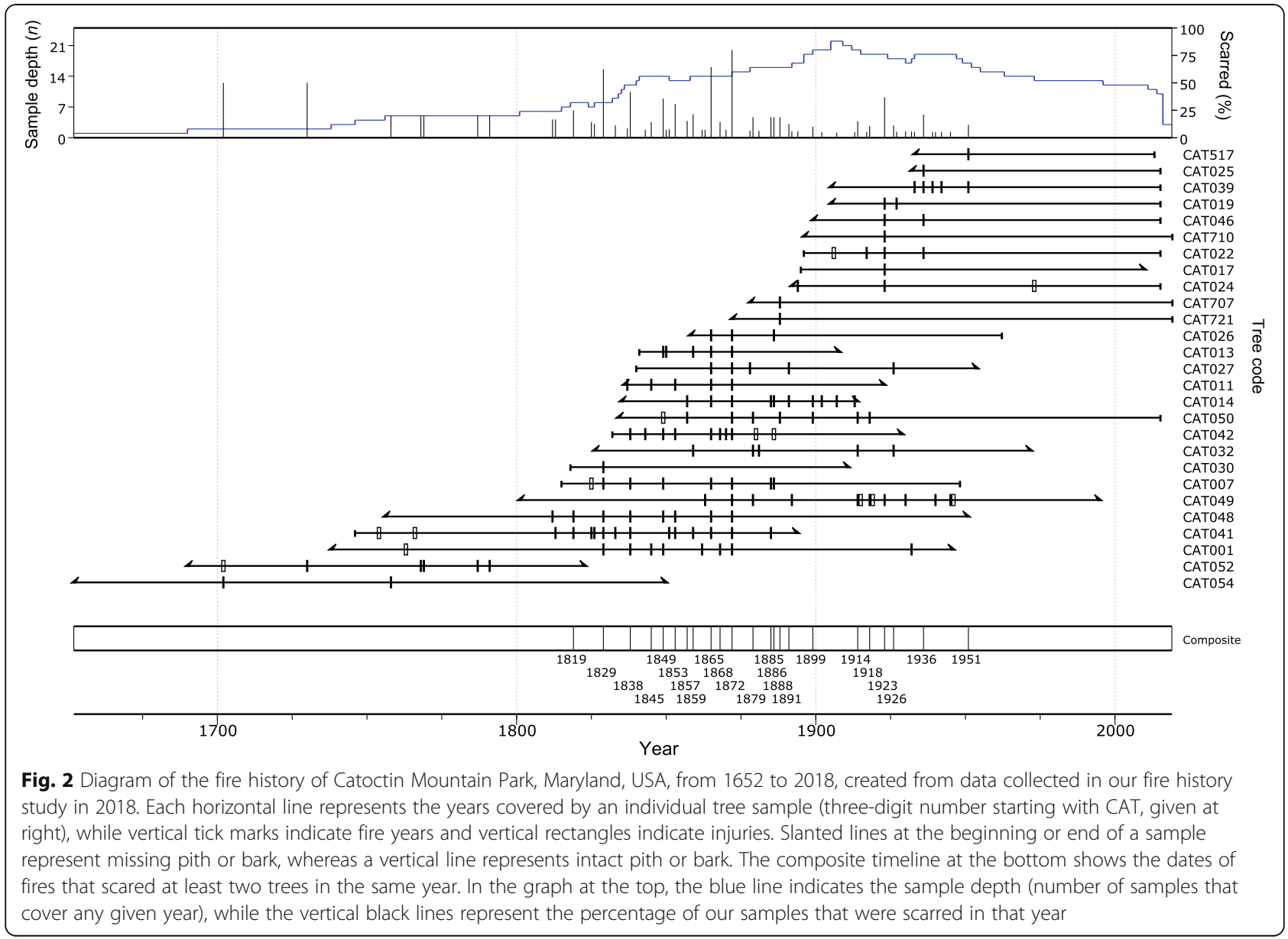


(95.5\%) fire scars were dormant-season scars. Twentythree of the 58 fire years were recorded by scars on at least two trees. These fires with potentially greater extent ranged from 1819 to 1951, had a MFI of $8.70 \pm$ 13.47 (SD) yr, and WMI of 5.95 yr (Fig. 2, see composite). Fire years that were recorded on four or more trees were $1829,1838,1849,1853,1865,1872,1923$, and 1936.

At least 134 fires were documented in newspapers between 1837 and 1960, 33 of which were near or specifically on Catoctin Mountain. The MFI of these 33 fires was $5.27 \pm 11.46(\mathrm{SD}) \mathrm{yr}$ and the WMI was $2.84 \mathrm{yr}$. Sixteen of the 33 also appeared in our tree-ring record (Table 1). The number of days without rain preceding these 16 fires ranged from six to 30 days with a mean of 11.6 days (Midwestern Regional Climate Center 2020; National Oceanic and Atmospheric Administration 2020). Seventy-five percent of these fires scarred more than one tree, and several newspaper reporters described prolonged drought conditions. See Additional file 3 for example newspaper articles describing fires on Catoctin Mountain.

Years in which fires scarred multiple trees had a mean PDSI 1.15 units lower compared to years with only one fire-scarred tree (Welch two sample T-test $P=0.008$ with $t=2.78$ and $\mathrm{df}=46.6$; Fig. $3 \mathrm{~A}$ ). Fire years with multiple scars were also 1.05 units hotter and drier than the average year according to SEA $(P<0.001$; Fig. 3B). In addition, the year two years prior was 0.86 units wetter than average $(P=0.009)$.

\section{Current forest composition}

We measured 82 trees greater than $10 \mathrm{~cm} \mathrm{DBH}$ and four saplings, representing seven tree species: black gum (Nyssa sylvatica Marshall; 50\% of stems), chestnut oak (Quercus montana Willd.; 34\% of stems), scarlet oak (Quercus coccinea Münch.; 8\% of stems), pitch pine (Pinus rigida Mill.; 3\% of stems), black oak (Quercus velutina Lam.; $2 \%$ of stems), sassafras (Sassafras albidum [Nutt.] Nees; 1\% of stems), and American beech (Fagus grandifolia Ehrh.; 1\% of stems). The three oak species together accounted for $76 \%\left(26.5 \mathrm{~m}^{2} \mathrm{ha}^{-1}\right)$ of the basal area. While numerically abundant, small-diameter black gum only accounted for $14 \%\left(5 \mathrm{~m}^{2} \mathrm{ha}^{-1}\right)$ of the basal area. Pitch pine accounted for only $9 \%\left(3.2 \mathrm{~m}^{2} \mathrm{ha}^{-1}\right)$ of the basal area. Ericaceous shrubs included Blue Ridge blueberries (Vaccinium pallidum Aiton), mountain laurel (Kalmia latifolia L.), and black huckleberry (Gaylussacia baccata [Wangenh.] K. Koch), all at or below 5 to $25 \%$ cover on the landscape. Leaf-litter depth in July 2016 ranged from 5 to $10 \mathrm{~cm}$, while duff depth ranged from 2.54 to $12.7 \mathrm{~cm}$. Deer impact in the study

Table 1 Historical newspaper articles reporting fires from the same years as the tree-ring record near or on Catoctin Mountain, Maryland, USA, from 1845 to 1942, used in our fire history study in 2018. Date reported is the date that newspapers recorded as the wildfire ignition date, not the date of the article. Fire scar seasonality by tree-ring follows Speer (2012). Days since wetting rain is the number of days without $>0.254 \mathrm{~cm}$ of rain. Cause of fire recorded as "incendiary" in the newspapers refer to human causation

\begin{tabular}{|c|c|c|c|c|}
\hline Date reported & Fire scar seasonality by tree-rings & Reporting newspaper name & Days since wetting rain & Cause of fire \\
\hline 16 Apr 1845 & Dormant & Catoctin Whig & 10 & None given \\
\hline 13 May 1857 & Undetermined & Hagerstown Herald & 9 & None given \\
\hline 11 May 1872 & Dormant & The Catoctin Clarion & 10 & Charcoal pits and incendiary \\
\hline 12 May 1879 & Dormant & Hagerstown Herald & 14 & None given \\
\hline 20 May 1885 & Dormant & The Washington Post & 24 & None given \\
\hline 8 May 1888 & Dormant & $\begin{array}{l}\text { The Washington Post, } \\
\text { The Catoctin Clarion }\end{array}$ & 7 & Incendiary \\
\hline 12 May 1891 & Dormant & The Baltimore Sun & 9 & None given \\
\hline 11 May 1899 & Dormant & The Catoctin Clarion & 5 & Incendiary or locomotive spark \\
\hline 15 Nov 1901 & Dormant & The Washington Post & 30 & None given \\
\hline 15 Dec 1913 & Dormant & The Frederick Post & 8 & None given \\
\hline 17 Nov 1917 & Dormant & The Frederick Post & 18 & None given \\
\hline 23 Apr 1923 & Dormant & $\begin{array}{l}\text { The Baltimore Sun, } \\
\text { The Frederick Post }\end{array}$ & 9 & Incendiary \\
\hline 9 Sep 1930 & Dormant & The Frederick Post & 13 & Incendiary \\
\hline 20 Apr 1936 & Early earlywood and dormant & The Frederick Post & 8 & Huckleberry pickers \\
\hline 13 Nov 1939 & Dormant & The Morning Herald' & 6 & Incendiary \\
\hline 17 Apr 1942 & Dormant & The News ${ }^{2}$ & 6 & None given \\
\hline
\end{tabular}

${ }^{1}$ Published in Hagerstown, Maryland

${ }^{2}$ Published in Frederick, Maryland 

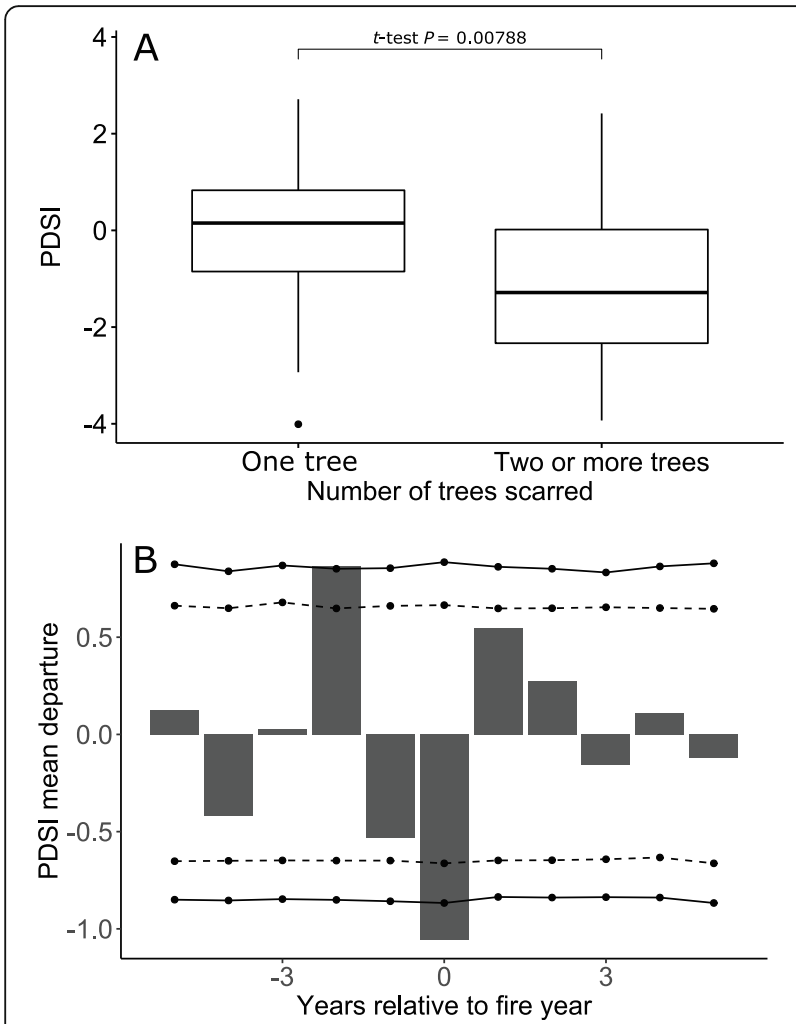

Fig. 3 Graph of relationship of historical fires (1702 to 1951) to drought at Catoctin Mountain Park, Maryland, USA, created from data collected in our fire history study in 2018. (A) Welch two sample $t$-test was used to compare mean Palmer Drought Severity Index (PDSI) between fire years that scarred one tree and those that scarred two or more trees. The box represents the 75th and 25th percentile around the median PDSI, whereas the vertical whisker represents 1.5 times the interquartile range. Dots are data points that are outliers. (B) Superposed Epoch Analysis of PDSI across all fire years represented by two or more fire-scarred trees. Bars above the center line indicate wetter and cooler than average conditions, whereas bars below the center line indicate hotter and drier conditions than average. The floating lines above and below the mean represent the 95\% (dashed) and 99\% (solid) confidence levels. The numbers on the $x$-axis represent the time lag before $(-)$ and after $(+)$ a fire year $(0)$

area was estimated to be high, with an intensity of 4 on a scale of 5 . Photographs of the study sites are available in Additional file 4.

Age structure of the 82 trees $\geq 10 \mathrm{~cm}$ DBH showed that the current forest was established between 1880 and 1930, but there was no significant linear relationship $\left(\mathrm{R}^{2}=0.046\right.$ and $\left.P=1\right)$ between a tree's age and its DBH. Oaks that we estimated were established in the 1920s and 30s spanned the entire range between 13 and $40 \mathrm{~cm}$ DBH. We sampled eight living pines that we estimated were established between 1880 and 1930. Three larger, older pine individuals located outside of the study plots were recruited to the site before the 1880s. Beginning in 1920, the main cohort of black gums and oaks that make up the majority of trees in the current forest reached $30 \mathrm{~cm}$ tall (coring height; Fig. 4). There was no tree recruitment inside our study area after the 1960s.

\section{Discussion}

\section{Historical role of fire}

Frequent fire was a part of the ecology of Catoctin Mountain for at least several hundred years, likely for millennia, due to lightning and Native American stewardship of the area (Tyndall 1992; Brown 2000; Stewart et al. 2002; Huffman 2013). Charcoal inputs to Chesapeake Bay sediments during four dry periods over the last 1000 years provide a long record of fire in the region (Brush 2001; Mitra et al. 2009). Beginning in the eighteenth century, some fires may have been set by European immigrants using fire to clear woods for agriculture (Rush 2005). An agricultural practice called swidden cultivation was employed by German and Scandinavian immigrants of the time, in which fire was used to clear land for grain crops and to encourage growth of resprouting tree species for coppicing (Sigaut 1979).

We developed an interpretive timeline that synthesized evidence of forest dynamics during the European colonization, industrialization, and fire suppression periods (Fig. 5). We focus our discussion on the xeric south and west facing slopes of Catoctin Mountain based on our historical investigation, dendrochronological reconstruction, and age structure analysis.

Prior to 1900, the charcoal-iron furnace industry (pictured in Additional file 5) promoted oak-sprout regeneration with a short rotation of cutting that coincided with frequent fires (Figs. 2, 5A). By the 1930s and 1940s, industrial use of the forest had stopped and firing for blueberry and huckleberry (Gaylussacia baccata [Wangenh.] $\mathrm{K}$. Koch) production was prohibited, leading to the establishment of the current cohort of trees (Fig. 5B). Oaks, having competitive saplings with already-established root systems (Brose et al. 2008), outgrew the black gums, suppressing them. The canopy was likely closed by the 1960s as no further recruitment occurred after this time (Figs. 4, 5C). Between the 1960s and present day, shade and deer changed forest dynamics, leading to a less diverse understory (Fig. 5D). For a detailed discussion of historical ignition sources during these time periods, please consult Additional file 1.

More than $95 \%$ of fire scars we recorded occurred during the dormant season. November and December fires reported in newspapers appeared as dormant-season fires at the beginning of the following year in our firescar record. When the newspaper dates and dendrochronological records of fire were combined, we found that fires in the spring as late as 20 May can appear in the tree-ring record as dormant, but an earlywood fire can be recorded as early as 20 April at Catoctin 


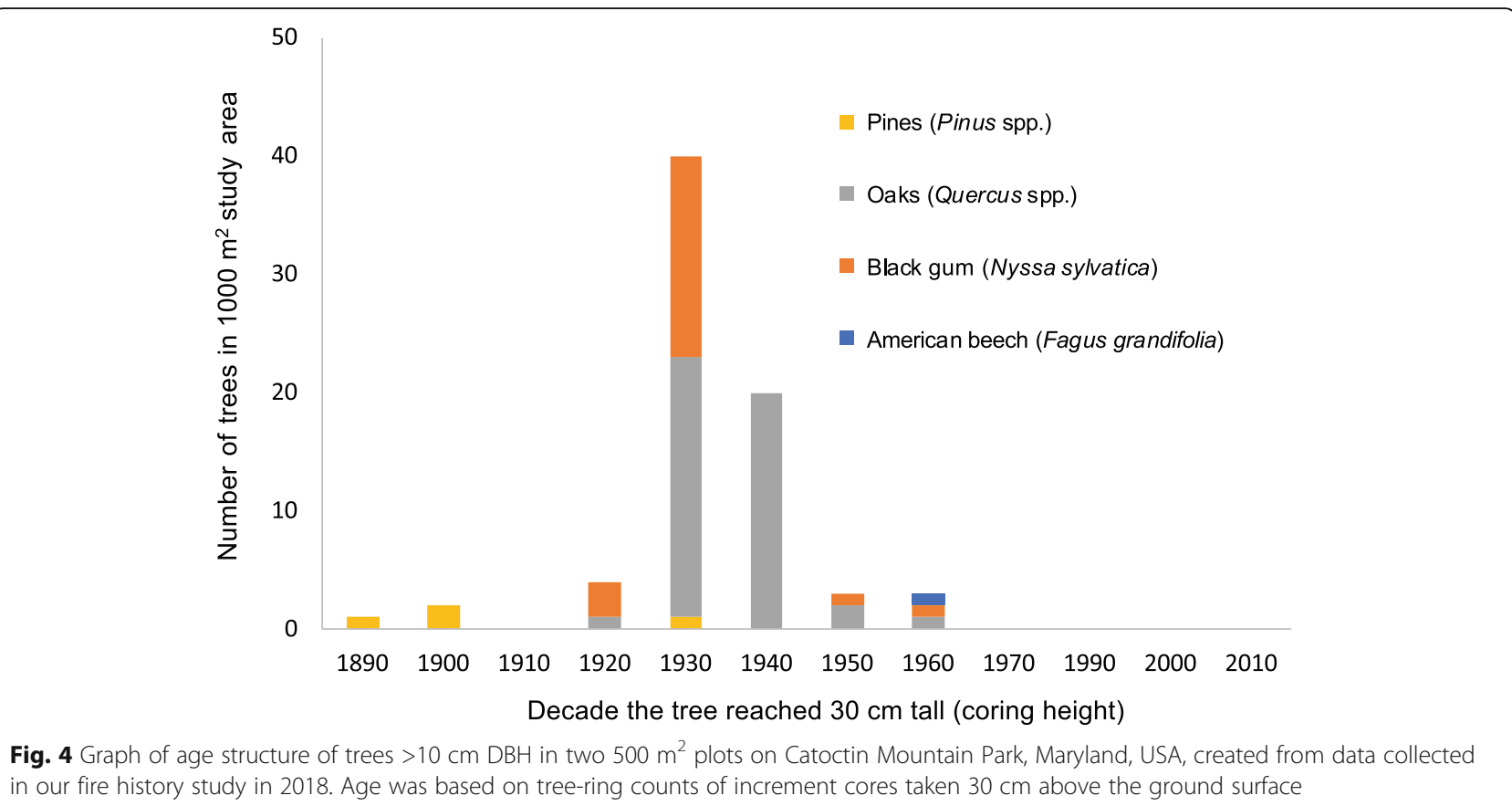

Mountain (Table 1). This variability in the timing of the dormant to earlywood transition could be due to variations in weather patterns year to year or collections of samples from different elevations. The dates of fires from newspaper articles compared to seasonality of fires recorded in tree-rings highlight the need for further investigation on timing of fires in the Appalachian
Mountains, similar to recent research in Coastal Plain pine savannas (Rother et al. 2018).

Both a $t$-test and Superposed Epoch Analysis (SEA) confirmed a significant effect of drought on tree scarring and fire occurrence, respectively (Figs. 3a, b). One important caveat is that the PDSI values used were the reconstructed summer (June to August) averages and,

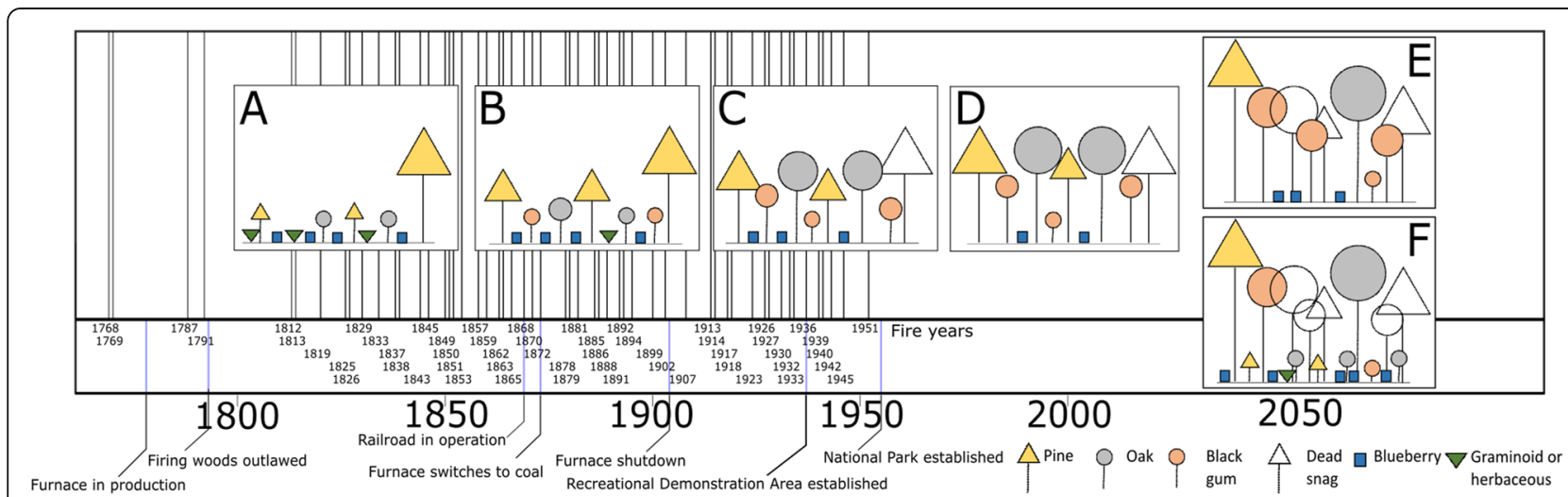

Fig. 5 Timeline for fires and characterizations of forest structure and composition on xeric south-and west-facing slopes at Catoctin Mountain Park, Maryland, USA, from 1750 to the present, created from data collected in our fire history study in 2018. Vertical black lines above the $x$-axis represent fire scar years, while blue lines below the $x$-axis represent the years of historical events. Insets show stand profile diagrams simplified from Howard (1983) to illustrate changes in forest vertical and horizontal structure through time, allowing comparison to the conceptual model in Nowacki and Abrams (2008): (A) charcoal-iron industry period; site dominated by sprout oaks, pitch pines, ericaceous shrubs, and graminoids; (B) blueberry cultivation after demise of the iron furnace industry; open structure as pines and oaks that previously established increase in size; (C) closed canopy forest forms after fire suppression; loss of graminoids and reduction in shrub cover; (D) current composition at the time of the study (2018); mature oak and pine overstory with black gum midstory and low shrub cover; (E) potential future with more fire exclusion; black gum increases in importance as oaks and pines die of old age without replacing themselves; (F) potential future incorporating burning and deer control; formation of canopy gaps by fire and thinning allows for oak and pine regeneration and the return of ericaceous shrubs and graminoids 
while some fires did occur in those months, the majority of fires in our study area took place during the spring and fall. Fires at the site could have occurred during discrete dry periods embedded in an otherwise wet year, weakening the correlation of fires scarring one tree to yearly PDSI. This was the case with at least some fires, as the average number of days without wetting rain (minimum $0.254 \mathrm{~cm}$ ) for the 16 fires recorded in both our study and in local newspapers was 11.6 days, but varied from six to 30 days (Table 1). There was a strong linear relationship between the number of consecutive dry days and the probability of ignition in the Ridge and Valley Province in West Virginia and Virginia, USA, from 1970 to 2001 (Lafon et al. 2017). Our SEA analysis also showed that wet, cool years with a PDSI higher than average occurred two years prior to fire events. A similar trend was found in the American Southwest in an oakpine system by Guiterman et al. (2015) and by Whitehair et al. (2018) on Navajo territory. The most likely mechanism is that an increased growth of fine fuels, such as grasses, facilitated fire spread during subsequent dry periods.

More fires probably occurred at Catoctin Mountain than we found, as we discovered many more newspaper accounts for additional fire dates. One likely explanation is that sample size can affect the calculation of fire interval (Aldrich et al. 2014; Lafon et al. 2017) because a shallow sample depth risks underreporting fire occurrence (Hutchinson et al. 2019). For example, we found many more fire dates than did Dobey et al. (1987), whose study dated eight fire-scarred trees. However the eighteenth century was represented by only five logs and stumps in our study, and we found long fire-free intervals during this period. These longer intervals may be a result of the historical depopulation of native peoples by disease and violence (as noted in northern Pennsylvania, USA, by Brose et al. 2013), or they are a sampling artifact. The oldest evidence had to survive the conflagrations and charcoal kilns of the nineteenth century as well as multitudes of carpenter ants (Camponotus pennsylvanicus De Geer, 1773), termites (Reticulitermes flavipes Kollar, 1837), and fungi to become part of our chronology. Thus, the fires we recorded at this time represent the minimum number of fires that could have occurred.

Our fire history shows that fire suppression had been very effective over the last 70 years. Catoctin Mountain Park was established as a Recreational Demonstration Area in 1936, which was a major fire year for the area as noted by the Frederick Post (Table 1). In this year alone, four sampled trees in our study as well as one of the eight trees in the study by Dobey et al. (1987) were scarred. In 1936 the Civilian Conservation Corps (CCC) set up a camp and began transforming the landscape by planting trees and building Park infrastructure; the
Frederick Post notes that the $\mathrm{CCC}$ helped extinguish multiple blazes that year. By the time the area became controlled by the National Park Service (NPS) in 1954, the last fire in our study area had already occurred in 1951. Records at NPS offices show that a few small wildfires (<1 ha) burned elsewhere in the Park after 1951, but no evidence of these wildfires was found in our study area. A 1941 photo of the visitor's center and our sampled hillside is available in Additional file 6.

\section{Consequences for forest dynamics}

A lack of fire has been cited as a key factor leading to transformation from an open, xeric, fire-adapted plant community into a closed, more shade-tolerant community that is resistant to future fires (Abrams 1992; Drury and Runkle 2006; Nowacki and Abrams 2008; Hanberry and Abrams 2019; Hanberry et al. 2020). No oak or pine saplings were found in our nested plots, but also none of the oak trees larger than $10 \mathrm{~cm}$ DBH were recruited to coring height after the 1960s in the $1000 \mathrm{~m}^{2}$ area that we sampled. While we recognize that this sampled area was small, it was centrally located among the firescarred pines; thus, all trees were subjected to the specific fire history we reconstructed.

A combination of environmental factors may be preventing a new generation of oak and pine trees from becoming established in our study area. Shade as well as the 8 to $23 \mathrm{~cm}$ of leaf litter and duff has probably kept pines from regenerating for over a century (Burns and Honkala 1990). However, a low-density oak-pine canopy should not prevent germination of acorns, the transition of seedlings into saplings, or the recruitment of saplings into the $\geq 10 \mathrm{~cm}$ DBH class. An alternate explanation is whitetailed deer (Odocoileus virginianus Zimmerman, 1780) herbivory. When the Park was established in 1936, deer populations were likely either at extremely low numbers or non-existent (National Park Service 2007). This time period correlates with the highest oak regeneration (Fig. 4). After that time, hunting was prohibited. We found frequent evidence of deer, including scat, tracks, deer trails, and browsed vegetation. Deer eat leaves, young twigs, sprouts, seedlings, and acorns, as well as rub the velvet off their antlers on saplings, causing stem injury. Oaks and black gums are preferred and nutritious food plants for deer (Rawinski 2014), but recent research has also found no relationship between deer densities and tree stocking (Hanberry and Abrams 2019).

Black gum is a shade-tolerant semi-mesophyte (Abrams 2007; Vose and Elliott 2016) tree that could facilitate a transition into a more mesic state. Black gum can survive in wet habitats and has leaves that lie flat and may collect moisture similar to those of red maple (Acer rubrum L.), a classic mesophytic species (Vose and Elliott 2016; Kreye et al. 2018). Smaller black gums were 
suppressed and of similar age to the larger oaks (Fig. 4). Oaks most likely grew more quickly than black gums, shading them enough to stunt their growth but not kill them. Although black gums are resprouters, they are classified as shade tolerant, and existing midstory individuals can recruit into the canopy following disturbance (Burns and Honkala 1990; Abrams 2007). A future canopy disturbance, such as an ice storm or gypsy moth (Lymantria dispar Linnaeus, 1758) outbreak, could accelerate a transition in forest composition to shadetolerant species (Abrams and Nowacki 1992). There are few or no competitive oak seedlings available at this study site to replenish the oak canopy or compete with black gum saplings (Brose et al. 2008; Fig. 5E). Although oak regeneration was documented in the absence of recent fires by Heeter et al. (2019) on Dan's Mountain in western Maryland, their ridgeline study site was more environmentally extreme than Catoctin Mountain. However, Heeter et al. (2019) also found a lack of Table Mountain pine (Pinus pungens Lamb.) and pitch pine regeneration after 1975 and suggested that this trend would continue without fire management.

Nowacki and Abrams (2008) suggested a mix of fire and silviculture to address the challenges posed by mesophication in oak forests. A review of the oak-fire literature by Brose et al. (2014) showed that a single burn alone was usually unsuccessful in regenerating oaks in the eastern US. Management must create environmental conditions favorable for seedling establishment, and light at the forest floor is important for the development of healthy resilient oak sprouts that can compete with mesic hardwoods and secure gaps when they appear overhead (Brose et al. 2014). At our study site, these conditions were met historically by the disturbances created by the charcoal-iron industry and blueberry cultivation until the 1930s (see Additional file 1). Thinning can be used in conjunction with fire to reduce basal area to prioritize oak regeneration (e.g., shelterwood-burn technique of Brose et al. 1999). Alternatively, fire alone can create gaps of varying size due to its heterogeneous severity on the landscape, particularly when repeated three to five times within ten to 15 years (Hutchinson et al. 2012; Lorber et al. 2018). That fire interval is comparable to what occurred during the charcoal-iron period at Catoctin Mountain, but a longer interval ( 7 to $8 \mathrm{yr}$ WMI, up to $19 \mathrm{yr}$, documented by Shumway et al. 2001 on Savage Mountain) facilitated the persistence of established oak forest for hundreds of years in western Maryland. Vose and Elliott (2016) highlighted the need for future research on the effects of fire management in relation to a changing climate, as interactions among drought, fire, invasive species, and other factors may create novel ecosystems with no historical analog.

\section{Conclusions}

Our dendrochronological study demonstrated that fire was a key historical ecological factor on Catoctin Mountain in western Maryland from at least 1702 through 1951, with MFI and seasonality comparable to fires in the wider Central Appalachian region (Brose et al. 2014; Lafon et al. 2017). Anthropogenic causes of historical fires included accidental and intentional ignition sources associated with blueberry production, agriculture, and the charcoal-iron industry. Extensive fires that scarred multiple trees were specifically tied to droughts and were often preceded by wet years. Newspapers provided a seasonal resolution and first person accounts not normally available in fire history studies. Reintroducing fire and controlling deer herbivory at Catoctin Mountain could create open structure and vertical heterogeneity, establish a new cohort of oak and pine saplings in the understory, and rejuvenate the shrub and herb layer (Fig. 5F). Developing a long-term fire management strategy could also help reverse the loss of herbaceous diversity and rare species that typically occurs in firesuppressed oak-pine ecosystems (Frost 1998; Rooney et al. 2004; Howard 2015; Hanberry et al. 2020; Vander Yacht et al. 2020).

\section{Supplementary Information}

The online version contains supplementary material available at https://doi. org/10.1186/s42408-021-00096-2.

Additional file 1. Material used in the construction of our interpretive timeline (Fig. 5) created from data from our fire history study on Catoctin Mountain, Maryland, USA, in 2018. It also contains additional historical and cultural context for the events recorded in the main section of the article (references not cited in the article main text but cited in Additional file 1 are: Bedell et al. 2011a; Bedell et al. 2011b; Clarkson 1964; Contract Archaeology, Inc. 1971; Coville 1910; Duchesne \& Wetzel 2004; Geasey \& Ballweber 1991; Hoefs \& Shay 1981; Library Of Congress 2020; Maryland Historical Trust 2018; Maryland State Archives 2019; Mash 1996; National Heritage Corporation 1975; National Park Service 2018; National Park Service 2020b; Rountree \& Davidson 1997; Stewart 1987; Stewart 1989; Wehrle 2000; Williams \& McKinsey 1910).

Additional file 2. "Catface" of a scarred, living pitch pine (Pinus rigida Mill.), found on Catoctin Mountain, Maryland, USA, in 2018, depicting at least seven nested fire scars. This tree was inside our fire history study area but not destructively sampled by request of the National Park Service. Photo credit: L. Howard.

Additional file 3. Labeled partial cross-section of a Table Mountain pine (Pinus pungens Lamb.; sample number CAT050) collected in 2018 from Catoctin Mountain Park, Maryland, USA, during our fire history study. Example corresponding newspaper accounts of droughts and fires from the Baltimore Sun are matched up with narrow tree-rings and fire scars on the sample. Seasonality of fire scars: $e=$ earlywood injury; $D=$ dormant season fire scar. Photo credit for cross-section: G. Cahalan.

Additional file 4. Representative photographs of the chestnut oak (Quercus montana Willd.) forest with black gum (Nyssa sylvatica Marshall) midstory at our fire history study sites at Catoctin Mountain Park, Maryland, USA, in 2016. The forest had not burned since 1951, leading to (A) a closed forest canopy with (B) a shaded understory with little plant diversity. Mountain laurels (Kalmia latifolia L.) over $3 \mathrm{~m}$ tall and sparse blueberry (Vaccinium L.) and black huckleberry (Gaylussacia baccata [Wangenh.] K. Koch) speak to the long-term absence of fire at the site. Note the deer trail leading through the middle of $(\mathbf{C})$ and the absence of tree seedlings and saplings in $(\mathbf{B})$ and $(\mathbf{C})$. Photo credits: L. Howard. 
Additional file 5. Nineteenth century photograph of the Catoctin Iron Furnace complex, Thurmont, Maryland, USA. Charcoal from our fire history study area would have been used to feed the furnaces to smelt pig iron from raw ore. Photo credit: Maryland Department of Natural Resources.

Additional file 6. Catoctin Mountain Park visitor's center, Maryland, USA circa 1941. The hillside in the background is the hillside that we sampled for fire history and current vegetation in 2018. Notice the young oak canopy with pines emerging above it. Photo credit: National Park Service.

\section{Acknowledgements}

Arcadia University's Office of Sponsored Research and Programs was instrumental in coordinating the The Nature Conservancy grant. Thank you, N. Shablia and C. Varma. Thank you to Arcadia alumni D. DiMarco, K. McGrath, and N. Sienkiewicz for conducting the fieldwork with LH and GC in the summer of 2016. Thank you also to a group of high school students and their leaders from the Student Conservation Association for helping us carry dozens of heavy samples down the mountain. We are also grateful to Catoctin Mountain Park and the National Park Service for hosting the project and approving necessary permits. L. Donaldson and R. Loncosky were extremely helpful in that regard. Thank you to J.A.J. Howard, L.D. Howard, D. Landau, M. Huffman, G. Tayac, J.M. Varner, and two anonymous reviewers for your thoughtful comments on the manuscript.

\section{Authors' contributions}

LH and GC designed and initiated the study. LH and GC collected samples. $\mathrm{LH}, \mathrm{GC}, \mathrm{SD}, \mathrm{KE}, \mathrm{HH}$, and BM processed samples, measured them, and analyzed the data. LH and GC wrote the first draft of the manuscript. LH, GC, $\mathrm{SD}, \mathrm{KE}, \mathrm{HH}$, and $\mathrm{BM}$ revised and edited the draft. All authors read and approved the final manuscript.

\section{Funding}

This project was made possible by a research grant from the Maryland/D.C. Chapter of The Nature Conservancy and donor J. Krusberg. Arcadia University's College of Arts and Sciences provided LH with Faculty Development Funds, as well as work study funding and Summer Housing Grants for students working in LH's dendrochronology lab. Arcadia University's Biology Department provided Summer Research Funding. Arcadia University provided an Instructional Technology Grant that doubled the sample-processing capacity of LH's dendrochronology laboratory and helped speed up the work.

\section{Availability of data and materials}

The datasets used or analyzed during the current study are available from the corresponding author on reasonable request.

\section{Declarations}

\section{Ethics approval and consent to participate}

Not applicable.

\section{Consent for publication}

Not applicable.

\section{Competing interests}

The authors declare that they have no competing interests.

\section{Author details}

${ }^{1}$ Department of Biology, Arcadia University, 450 S. Easton Road, Glenside, Pennsylvania 19038, USA. ${ }^{2}$ The Nature Conservancy, 425 Barlow Place, Suite 100, Bethesda, Maryland 20814, USA.

\section{Received: 11 May 2020 Accepted: 18 February 2021}

Published online: 24 March 2021

\section{References}

Abrams, M.D. 1992. Fire and the Development of Oak Forests. BioScience 42: 346-353 https://doi.org/10.2307/1311781

Abrams, M.D. 2003. Where has all the white oak gone? Bioscience 53 (10): 927-939 https://doi.org/10.1641/0006-3568(2003)053[0927:WHATWO]2.0.CO;2.
Abrams, M.D. 2007. Tales from the Blackgum, a Consummate Subordinate Tree. Bioscience 57 (4): 347-359 https://doi.org/10.1641/B570409.

Abrams, M.D., and G.J. Nowacki. 1992. Historical Variation in Fire, Oak Recruitment, and Post-Logging Accelerated Succession in Central Pennsylvania. Bulletin of the Torrey Botanical Club 119: 19-28 https://doi.org/10.2307/2996916.

Aldrich, S.R., C.W. Lafon, H.D. Grissino-Mayer, and G.G. DeWeese. 2014. Fire history and its relations with land use and climate over three centuries in the central Appalachian Mountains, USA. Journal of Biogeography 41 (11): 2093-2104 https://doi.org/10.1111/jbi.12373.

Arno, S.F., and Sneck, K.M. 1977. A method for determining fire history in coniferous forests of the Mountain West. USDA Forest Service, Intermountain Forest and Range Experiment Station, Ogden, Utah, Gen. Tech. Rep. INT-GTR-42.

Ballard, J.P., S.P. Horn, and Z.-H. Li. 2017. A 23,000-year microscopic charcoal record from Anderson Pond, Tennessee, USA. Palynology 41: 216-229 https:// doi.org/10.1080/01916122.2016.1156588.

Bedell, J., G. Katz, J. Shellenhamer, L. Kraus, and S. Groesbeck. 2011a. The people of the mountain archeological overview, assessment, identification, and evaluation study of Catoctin Mountain Park Maryland, National Park Service National Capital Region, Washington, D.C. Vol. 2.

Bedell, J., G. Katz, J. Shellenhamer, L. Kraus, and S. Groesbeck. 2011 b. The people of the mountain archeological overview, assessment, identification, and evaluation study of Catoctin Mountain Park Maryland, National Park Service National Capital Region, Washington, D.C. Vol. 1.

Beller, E.E., L. McClenachan, E.S. Zavaleta, and L.G. Larsen. 2020. Past forward: Recommendations from historical ecology for ecosystem management. Global Ecology and Conservation 21: e00836 https://doi.org/10.1016/j.gecco.2 019.e00836.

Brewer PW 2014. Tellervo: A guide for users and developers. http://www.tellervo. org/support/tellervo-manual.pdf

Brezinski, DK 1992. Lithostratigraphy of the western Blue Ridge cover rocks in Maryland. Maryland Geological Survey

Briand, C.H., and M.E. Folkoff. 2019. Integrating Multiple Sources to Reconstruct the Pre- and Early Postcolonial Forests of the Chesapeake: 1588-1838. Human Ecology 47: 27-38 https://doi.org/10.1007/s10745-019-0058-7.

Brose, P.H., D.C. Dey, R.P. Guyette, J.M. Marschall, and R.C. Stambaugh. 2013. The influences of drought and humans on the fire regimes of northern Pennsylvania, USA. Canadian Journal of Forest Research 43: 757-767 https:// doi.org/10.1139/cjfr-2012-0463.

Brose PH, Dey DC, and Waldrop TA 2014. The fire-oak literature of eastern North America: synthesis and guidelines. U.S. Department of Agriculture, Forest Service, Northern Research Station, Newtown Square, PA. https://doi.org/10.2 737/NRS-GTR-135

Brose PH, Gottschalk KW, Horsley SB, Knopp PD, Kochenderfer JN, McGuinness BJ, Miller GW, Ristau TE, Stoleson SH, and Stout SL 2008. Prescribing regeneration treatments for mixed-oak forests in the Mid-Atlantic region. https://doi.org/10.2 737/NRS-GTR-33

Brose, P.H., D.H. Van Lear, and P.D. Keyser. 1999. A Shelterwood-Burn Technique for Regenerating Productive Upland Oak Sites in the Piedmont Region. Southern Journal of Applied Forestry 23 (3): 158-163 https://www.srs.fs.fed.us/ pubs/ja/ja_brose002.pdf, https://doi.org/10.1093/sjaf/23.3.158.

Brown, H. 2000. Wildland burning by American Indians in Virginia. Fire Management Today. 60: 11.

Brown JK 1974. Handbook for inventorying downed woody material. U.S Department of Agriculture, Forest Service, Intermountain Forest and Range Experiment Station, Ogden, UT

Brush, G.S. 2001. Forests before and after the Colonial Encounter. In Discovering the Chesapeake: the History of an Ecosystem, ed. P.D. Curtin, G.S. Brush, and G. W. Fisher, 40-59. Johns Hopkins University Press.

Bunn, A.G. 2008. A dendrochronology program library in R (dp/R). Dendrochronologia 26: 115-124 https://doi.org/10.1016/j.dendro.2008.01.002.

Bunn, A.G. 2010. Statistical and visual crossdating in R using the dpIR library. Dendrochronologia 28: 251-258 https://doi.org/10.1016/j.dendro.2009.12.001.

Burns RM and Honkala BH 1990. Silvics Manual Volume 1-Conifers and Volume 2Hardwoods. U.S. Department of Agriculture, Forest Service, Washington, D.C. https://www.srs.fs.usda.gov/pubs/misc/ag_654/table_of_contents.htm

Clarkson, R.B. 1964. Tumult on the Mountains: Lumbering in West Virginia 1770 1920. McClain Printing Company.

Contract Archaeology, Inc. 1971. An Historical and Archeological Survey: Land Affected by Dualization of U.S. Route 15 at the Catoctin Iron Furnace

Cook, ER, R. Seager, R.R. Heim Jr, R.S. Vose, C. Herweijer, and C. Woodhouse 2010. Megadroughts in North America: placing IPCC projections of 
hydroclimatic change in a long-term palaeoclimate context. Journal of Quaternary Science 25: 48-61 https://doi.org/10.1002/jqs.1303.

Coville FV 1910. Experiments in Blueberry Culture. U.S. Department of Agriculture. Bureau of Plant Industry. Bulletin No. 193. Government Printing Office. Washington, D.C. https://books.google.com/books?id=PcIJAAAAYAAJ

de Graauw, K.K., and A.E. Hessl. 2020. Do historic log buildings provide evidence of reforestation following depopulation of Indigenous Peoples? Journal of Biogeography 47: 630-642 https://doi.org/10.1111/jbi.13769.

Dobey, D.C., H.F. Garazo, P. Strider, and K. Langdon. 1987. A fire history analysis of Catoctin Mountain Park. Proceedings of the Pennsylvania Academy of Science 61 (2): 177-180

Drury, S.A., and J.R. Runkle. 2006. Forest vegetation change in southeast Ohio: Do older forests serve as useful models for predicting the successional trajectory of future forests? Forest Ecology and Management 223 (2006): 200-210 https://doi.org/10.1016/j.foreco.2005.11.001.

Duchesne, L.C., and S. Wetzel. 2004. Effect of Fire Intensity and Depth of Burn on Lowbush Blueberry, Vaccinium angustifolium, and Velvet Leaf Blueberry, Vaccinium myrtilloides, Production in Eastern Ontario. The Canadian FieldNaturalist 118: 195-200 https://doi.org/10.22621/cfn.v118i2.913.

Flatley, W.T., C.W. Lafon, H.D. Grissino-Mayer, and L.B. LaForest. 2013. Fire history, related to climate and land use in three southern Appalachian landscapes in the eastern United States. Ecological Applications 23: 1250-1266 https://doi. org/10.1890/12-1752.1.

Frost, C.C. 1998. Presettlement fire frequency regimes of the United States: a first approximation. In Proceedings of the 20th Tall Timbers Fire Ecology Conference. Tall Timbers Research, Inc., Tallahassee, FL, 70-81.

Geasey, S.O., and H.L. Ballweber. 1991. Prehistoric utilization of the highland metarhyolite outcrop in the Maryland Blue Ridge Province. Archaeology of Eastern North America 19: 75-114.

Grissino-Mayer, H.D., J.T. Maxwell, G.L. Harley, N.A. Garland, D.H. Holt, B.J. Absherd Beale, M.S. Boehm, K.A. de Graauw, A.-M. Rautio, and A.W. Dye. 2013. Dendrochronology reveals the construction history of an early 19th century farm settlement, southwestern Virginia, USA. Journal of Archaeological Science 40: 481-489 https://doi.org/10.1016/j.jas.2012.05.038.

Guiterman, C.H., E.Q. Margolis, and T.W. Swetnam. 2015. Dendroecological Methods For Reconstructing High-Severity Fire In Pine-Oak Forests. Tree-Ring Research 71: 67-77 https://doi.org/10.3959/1536-1098-71.2.67.

Guyette, R.P., M.C. Stambaugh, D.C. Dey, and R.-M. Muzika. 2012. Predicting Fire Frequency with Chemistry and Climate. Ecosystems 15: 322-335 https://doi. org/10.1007/s10021-011-9512-0.

Hanberry, B.B., and M.D. Abrams. 2019. Does white-tailed deer density affect tree stocking in forests of the Eastern United States? Ecological Processes 8: 30 https://doi.org/10.1186/s13717-019-0185-5.

Hanberry, B.B., D.C. Bragg, and H.D. Alexander. 2020. Open forest ecosystems: An excluded state. Forest Ecology and Management 472 https://doi.org/10.1016/j. foreco.2020.118256.

Harley, G.L., C.H. Baisan, P.M. Brown, D.A. Falk, W.T. Flatley, H.D. Grissino-Mayer, A. Hessl, E.K. Heyerdahl, M.W. Kaye, C.W. Lafon, E.Q. Margolis, R.S. Maxwell, A.T. Naito, W.J. Platt, M.T. Rother, T. Saladyga, R.L. Sherriff, L.A. Stachowiak, M.C. Stambaugh, E.K. Sutherland, and A.H. Taylor. 2018. Advancing Dendrochronological Studies of Fire in the United States. Fire 1 (1): 11 https://doi.org/10.3390/fire1010011.

Hart, J.L., S.P. Horn, and H.D. Grissino-Mayer. 2008. Fire history from soil charcoal in a mixed hardwood forest on the Cumberland Plateau, Tennessee, USA. Journal of the Torrey Botanical Society 135: 401 https://doi.org/10.3159/08-RA-013.1.

Heeter, K.J., S.L. Brosi, and G.L. Brewer. 2019. Dendroecological Analysis of Xeric, Upland, Quercus-Dominated Old-Growth Forest within the Ridge and Valley Province of Maryland, USA. Natural Areas Journal 39: 319-332 https://doi. org/10.3375/043.039.0304.

Hessl, A.E., T. Saladyga, T. Schuler, P. Clark, and J. Wixom. 2011. Fire history from three species on a central Appalachian ridgetop. Canadian Journal of Forest Research 41: 2031-2039 https://doi.org/10.1139/x11-125.

Hoefs, M.E.G., and J.M. Shay. 1981. The effects of shade on shoot growth of Vaccinium angustifolium Ait. after fire pruning in southeastern Manitoba. Canadian Journal of Botany 59: 166-174 https://doi.org/10.1139/b81-027.

Horn, S.P., M.S. Boehm, and J.P. Ballard. 2019. An improved chronology for the microscopic charcoal and pollen records from Anderson Pond, Tennessee, USA. Palynology 43: 517-522 https://doi.org/10.1080/01916122.2018.1509150.

Howard, L.D. 1983. A Simple System for Relating Physiognomy, Floristic Composition and Relative Importance in Woody Vegetation. Bulletin of the Torrey Botanical Club 110: 360-365 https://doi.org/10.2307/2996191.
Howard, L.F. 2015. A Quarter-Century of Change Without Fire: The High-Elevation Pitch Pine Community on Panther Knob, Pendleton County, West Virginia. Castanea 80: 193-210 https://doi.org/10.2179/15-052.

Huffman, M.R. 2013. The Many Elements of Traditional Fire Knowledge: Synthesis, Classification, and Aids to Cross-cultural Problem Solving in Fire-dependent Systems Around the World. Ecology and Society 18: 4. https://doi.org/10.5751/ ES-05843-180403. https://doi.org/10.5751/ES-05843-180403.

Hutchinson, T.F., R.P. Long, J. Rebbeck, E.K. Sutherland, and D.A. Yaussy. 2012. Repeated prescribed fires alter gap-phase regeneration in mixed-oak forests. Canadian Journal of Forest Research 42: 303-314 https://doi.org/10.1139/x11-184

Hutchinson, T.F., M.C. Stambaugh, J.M. Marschall, and R.P. Guyette. 2019. Historical fire in the Appalachian Plateau of Ohio and Kentucky, USA, from remnant yellow pines. Fire Ecology 15: 33 https://doi.org/10.1186/s42408-019-0052-x.

Keane, R.E., P.F. Hessburg, P.B. Landres, and F.J. Swanson. 2009. The use of historical range and variability (HRV) in landscape management. Forest Ecology and Management 258: 1025-1037 https://doi.org/10.1016/j.foreco.2 009.05.035.

Kirwan, J., and H. Shugart. 2000. Vegetation and Two Indices of Fire on the Delmarva Peninsula. The Journal of the Torrey Botanical Society 127 (1): 44-50 https://doi.org/10.2307/3088746.

Kreye, J.K., J.M. Varner, G.W. Hamby, and J.M. Kane. 2018. Mesophytic litter dampens flammability in fire-excluded pyrophytic oak-hickory woodlands. Ecosphere 9: e02078 https://doi.org/10.1002/ecs2.2078.

Lafon CW, Naito AT, Grissino-Mayer HD, Horn SP, and Waldrop TA 2017. Fire history of the Appalachian region: a review and synthesis. U.S. Department of Agriculture, Forest Service, Southern Research Station, Asheville, NC. https:// www.srs.fs.usda.gov/pubs/gtr/gtr_srs219.pdf, https://doi.org/10.2737/SRSGTR-219

Library Of Congress 2020. Railroad Maps, 1828-1900 | Digital Collections. https:// www.loc.gov/collections/railroad-maps-1828-to-1900/about-this-collection/. Accessed 24 Apr 2020

Lorber J, Thomas-Van Gundy M, and Croy S 2018. Characterizing effects of prescribed fire on forest canopy cover in the George Washington and Jefferson National Forests. U.S. Department of Agriculture, Forest Service, Northern Research Station, Newtown Square, PA. https://doi.org/10.2737/ NRS-RP-31

Malevich, S.B., C.B. Guiterman, and E.Q. Margolis. 2018. burnr: Fire history analysis and graphics in R. Dendrochronologica 49 (2018): 9-15 https://doi.org/10.101 6/j.dendro.2018.02.005.

Marschall, J., M. Stambaugh, B. Jones, R.P. Guyette, P.H. Brose, and D.C. Dey. 2016. Fire Regimes of Remnant Pitch Pine Communities in the Ridge and Valley Region of Central Pennsylvania, USA. Forests 7: 224 https://doi.org/10.3390/ f7100224.

Maryland Historical Trust 2018. National Register Properties in Maryland: Catoctin Mountain Park Historic District. https://mht.maryland.gov/nr/NRDetail.aspx?NRID= 1632\&COUNTY=Frederick\&FROM=NRCountyList.aspx. Accessed 24 Apr 2020

Maryland State Archives. 2019. Laws of Maryland. MSA SC M 3181: 680-681 https://msa.maryland.gov/megafile/msa/speccol/sc4800/sc4872/003181/html/ m3181-0681.html.

Mash, J. 1996. The Land of the Living: The Story of Maryland's Green Ridge Forest, The Living History Foundation of Allegany County. 1st ed.

Midwestern Regional Climate Center 2020. MRCC - Data \& Services: 19th Century Weather (FORTS). https://mrcc.illinois.edu/data_serv/cdmp/cdmp.jsp. Accessed 24 Apr 2020

Mitra, S., A.R. Zimmerman, G.B. Hunsinger, D. Willard, and J.C. Dunn. 2009. A Holocene record of climate-driven shifts in coastal carbon sequestration. Geophysical Research Letters 36: L05704 https://doi.org/10.1029/2008GL036875.

National Heritage Corporation 1975. Catoctin Iron Furnace: A Report on An Historical Survey.

National Oceanic \& Atmospheric Administration 2020. Climate Data Online (CDO) - The National Climatic Data Center's (NCDC) Climate Data Online (CDO) provides free access to NCDC's archive of historical weather and climate data in addition to station history information. | National Climatic Data Center (NCDC). https://www.ncdc.noaa.gov/cdo-web/. Accessed 25 Apr 2020

National Park Service 2007. Final white-tailed deer management plan / environmental impact statement: Catoctin Mountain Park. https:/parkplanning.nps.gov/ document.cfm?parkID=176\&projectID=10003\&documentID=25018

National Park Service 2018. Catoctin Iron Furnace - Catoctin Mountain Park (U.S. National Park Service). https://www.nps.gov/cato/learn/historyculture/furnace. htm. Accessed 9 Dec 2019 
National Park Service 2020a. Catoctin Rocks! - Catoctin Mountain Park (U.S. National Park Service). https://www.nps.gov/cato/learn/kidsyouth/activity9.htm. Accessed 25 Apr 2020

National Park Service 2020b. Canal Construction - Chesapeake \& Ohio Canal National Historical Park (U.S. National Park Service). https://www.nps.gov/ choh/learn/historyculture/canalconstruction.htm. Accessed 25 Apr 2020

NatureServe. 2021. NatureServe Explorer. https://explorer.natureserve.org/Taxon/ ELEMENT_GLOBAL.2.687624/Pinus_(pungens_rigida)_-_Quercus_montana_-(Quercus_ilicifolia)_-_Gaylussacia_baccata_Woodland. Accessed 22 Jan 2021.

North American Drought Atlas 2019. Requested Map. http://drought.memphis. edu/NADAV. Accessed 11 Dec 2019

Nowacki GJ and Abrams MD 2008. The Demise of Fire and "Mesophication" of Forests in the Eastern United States. https://doi.org/10.1641/B580207

R Core Team 2019. The Comprehensive R Archive Network. https://cran.r-project. org/. Accessed 25 Apr 2020

Rawinski TJ 2014. White-tailed Deer in Northeastern Forests. U.S. Department of Agriculture, Forest Service, Northeast Research Station, Newtown Square, PA

Razali, N.M., and Y.B. Wah. 2011. Power Comparisons of Shapiro-Wilk, Kolmogorov-Smirnov, Lilliefors and Anderson-Darling Tests. Journal of Statistical Modeling and Analytics 2 (1): 21-33.

Rooney, T.P., S.M. Wiegmann, D.A. Rogers, and D.M. Waller. 2004. Biotic Impoverishment and Homogenization in Unfragmented Forest Understory Communities. Conservation Biology 18: 787-798 https://doi.org/10.1111/j.1 523-1739.2004.00515.x.

Roos, C.I., D.J. Williamson, and D.M.J.S. Bowman. 2019. Is Anthropogenic Pyrodiversity Invisible in Paleofire Records? Fire 2: 42 https://doi.org/10.3390/ fire2030042.

Rother, M.T., J.M. Huffman, G.L. Harley, W.J. Platt, N. Jones, K.N. Robertson, and S.L. Orzell. 2018. Cambial Phenology Informs Tree-Ring Analysis of Fire Seasonality in Coastal Plain Pine Savannas. Fire Ecology 14: 164-185 https:// doi.org/10.4996/fireecology.140116418.

Rountree, H.C., and T.E. Davidson. 1997. Eastern Shore Indians of Virginia and Maryland. Charlottesville: University Press of Virginia.

Rush B 2005. An account of the manners of the German inhabitants of Pennsy/vania. http://name.umdl.umich.edu/AFJ8600.0001.001

Saladyga, T. 2017. Reconstructing a cultural fire regime in the Pennsylvania Anthracite Region. Physical Geography 38 (5): 404-422 https://doi.org/10.1 080/02723646.2017.1319727.

Shumway, D.L., M.D. Abrams, and C.M. Ruffner. 2001. A 400-year history of fire and oak recruitment in an old-growth oak forest in western Maryland, USA. Canadian Journal of Forest Research 31: 1437-1443 https://doi.org/10.1139/x01-079.

Sigaut, F. 1979. Swidden cultivation in Europe. A question for tropical anthropologists. Social Science Information 18: 679-694 https://doi.org/10.11 77/053901847901800403.

Silver, E.J., J.H. Speer, M. Kaye, N.J. Reo, L.F. Howard, A.K. Anning, S.W. Wood, and H.M. Wilbur. 2013. Fire History and Age Structure of an Oakpine Forest on Price Mountain, Virginia, USA. Natural Areas Journal 33: 440-446 https://doi. org/10.3375/043.033.0407

Speer, J. 2012. The Fundamentals of Tree-Ring Research. Tucson, AZ: University of Arizona Press.

Stambaugh, M.C., J.M. Marschall, E.R. Abadir, B.C. Jones, P.H. Brose, D.C. Dey, and R.P. Guyette. 2018. Wave of fire: an anthropogenic signal in historical fire regimes across central Pennsylvania, USA. Ecosphere 9: e02222 https://doi. org/10.1002/ecs2.2222.

Stewart, O.C., H.T. Lewis, and K. Anderson. 2002. Forgotten Fires: Native Americans and the Transient Wilderness. University of Oklahoma Press.

Stewart, R.M. 1987. Rhyolite quarry and quarry-related sites in Maryland and Pennsylvania. Archaeology of Eastern North America 1: 47-57.

Stewart, R.M. 1989. Trade and exchange in the Middle Atlantic region prehistory. Archaeology of Eastern North America 17: 47-78.

Sutherland, E.K., P.W. Brewer, M.E. Velasquez, and D.A. Falk. 2016. FHAES: The Fire History Analysis and Exploration System.

Thomas-Van Gundy, M.A., and G.J. Nowacki. 2013. The use of witness trees as pyro-indicators for mapping past fire conditions. Forest Ecology and Management 304: 333-344 https://doi.org/10.1016/j.foreco.2013.05.025.

Thomas-Van Gundy MA, Nowacki GJ, and Cogbill CV 2015. Mapping pyrophilic percentages across the northeastern United States using witness trees, with focus on four national forests. U.S. Department of Agriculture, Forest Service, Northern Research Station, Newtown Square, PA. https://doi.org/10.2737/NRS-GTR-145

Tyndall, R.W. 1992. Historical Considerations of Conifer Expansion in Maryland Serpentine "Barrens". Castanea 57: 123-131.
U.S. Department of Agriculture 2020. Web Soil Survey. https://websoilsurvey.sc egov.usda.gov/App/WebSoilSurvey.aspx. Accessed 25 Apr 2020

Vander Yacht, A.L., P.D. Keyser, S.A. Barrioz, C. Kwit, M.C. Stambaugh, W.K. Clatterbuck, and R. Jacobs. 2020. Litter to glitter: promoting herbaceous groundcover and diversity in mid-southern USA oak forests using canopy disturbance and fire. Fire Ecology 16: 17 https://doi.org/10.1186/s42408-02000072-2.

Vose, J.M., and K.J. Elliott. 2016. Oak, Fire, and Global Change in the Eastern USA: What Might the Future Hold? Fire Ecology 12: 160-179 https://doi.org/10.4 996/fireecology.1202160.

Wehrle EF 2000. Catoctin Mountain Park: Historic Resource Study. https://www.nps gov/parkhistory/online_books/cato/hrs.htm. Accessed 1 May 2020

Welch, B.L. 1938. The significance of the difference between two means when the population variances are unequal. Biometrika 29 (3/4): 350-362 https:// doi.org/10.1093/biomet/29.3-4.350

Wells, N., S. Goddard, and M.J. Hayes. 2004. A Self-Calibrating Palmer Drought Severity Index. Journal of Climate 17: 2335-2351 https://doi.org/10.1175/152 0-0442(2004)017<2335:ASPDSI>2.0.CO;2.

Western Regional Climate Center 2020. Catoctin Mtn Pk, Maryland - Climate Summary. https://wrcc.dri.edu/cgi-bin/cliMAIN.pl?md1530. Accessed 25 Apr 2020

Whitaker, J.C. 1955. Geology of Catoctin Mountain, Maryland and Virginia. GSA Bulletin 66: 435-462 https://doi.org/10.1130/0016-7606(1955)66[435:GOCMMA ]2.0.CO;2.

Whitehair, L., P.Z. Fulé, A.S. Meador, A. Azpeleta Tarancón, and Y.-S. Kim. 2018. Fire regime on a cultural landscape: Navajo Nation. Ecology and Evolution 8 . 9848-9858 https://doi.org/10.1002/ece3.4470.

Willard, D.A., T.M. Cronin, and S. Verardo. 2003. Late-Holocene climate and ecosystem history from Chesapeake Bay sediment cores, USA. The Holocene 13 (2): 201-214 https://doi.org/10.1191/0959683603hl607rp.

Williams TJC and McKinsey F 1910. History of Frederick County, Maryland, from the earliest settlements to the beginning of the war between the states. L. R. Titsworth \& co., Frederick, Md.

Yocom Kent, L.L., and P.Z. Fulé. 2015. Do Rules of Thumb Measure Up? Characteristics of Fire-Scarred Trees and Samples. Tree-Ring Research 71: 78-82 https://doi.org/10.3959/1536-1098-71.2.78.

\section{Publisher's Note}

Springer Nature remains neutral with regard to jurisdictional claims in published maps and institutional affiliations.

\section{Submit your manuscript to a SpringerOpen ${ }^{\circ}$ journal and benefit from:}

- Convenient online submission

- Rigorous peer review

- Open access: articles freely available online

High visibility within the field

- Retaining the copyright to your article

Submit your next manuscript at $>$ springeropen.com 